\title{
Enlightenment and Sociability in 18th-century Britain
}

\section{Yüzyıl Britanya'sında Aydınlanma ve Sosyalleşme}

\section{Derya Gürses Tarbuck, 18. Yüzyll Britanya'sında Aydınlanma ve Sosyallaşme. İstanbul: Muhayyel Yayıncılık 2021, 152 s. ISBN 978-605- 06414-2-4}

\section{Clifford Siskin ${ }^{1}[0$}

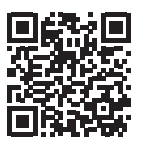

'Prof. Dr., New York University, College of Arts and Science, New York, USA

ORCID: C.S. XXXX-XXX-XXXX-XXXXX

Sorumlu yazar/Corresponding author:

Clifford Siskin, New York University, College of Arts and Science, New York, USA

E-posta/E-mail: clifford.siskin@nyu.edu

Başvuru/Submitted: 13.03 .2021 • Kabul/Accepted: 14.05 .2021

Atıf/Citation: Clifford Siskin “18. Yüzyıl Britanya'sında Aydınlanma ve Sosyalleşme," Derya Gürses Tarbuck'ın "18. Yüzyıl Britanyası'nda Aydınlanma ve Sosyalleşme" adlı eserinin tanıımı. Osman/ı Bilimi Araştırmaları 23, 1 (2021): 201-203. https://doi.org/10.26650/oba.2022001

Keywords: The Fair Intellectual Club, Sociability, Enlightenment, Britain

Anahtar Sözcükler: Adil Entelektüel Kulübü, Sosyalleşme, Aydınlanma, Britanya

This monograph takes on the important task of securing a wider audience for one of the most extraordinary documents of the Enlightenment. An Account of the Fair Intellectual Club (1720) describes a small, secret club of teenage women who came together in Edinburgh for the purpose of mutual self-improvement.-When word of their secret was about to leak, they took the proactive step of publishing this account of their venture. Their document is a milestone in the history of our modern notions of "intellectual" work and of the types of associations-such as clubs-that enabled it. Formed in the first quarter of the eighteenth 
century, the Club helps us to rethink the early chapters of our histories of gender and feminismand of their central role in the proliferation of the knowledge we call Enlightenment. Tarbuck has make a significant contribution to these reassessments by providing the first extended treatment of the Account. She takes on, in particular, three crucial tasks: the authenticity of the document, including a literature review, its philosophical contexts, including issues of gender, sociability and education, and key conceptual touchstones, including leisure, religion, and reason. Tarbuck is successful in illuminating all of these important areas of inquiry.

The literature review is particularly helpful in unravelling the secret itself: who were these women? By looking at multiple copies of the Account in different libraries, she has retrieved the best hints we have as to the individual identities of the members of the club: "hand-written notes on the British Library copy of An Account indicate that one member was a certain Hamilton, and the other a Bruce." Archival detective work at this level of specificity is not a trivial matter when a scholar is dealing with a text from a time period famous for its forgeries. And when that text is written by women, establishing its authenticity is especially important, since, until recently, they have been written out of the standard histories of Enlightenment. Tarbuck graciously notes my own efforts to write them back in-though future editions of this monograph should reference my most recent work on the Club SYSTEM: The Shaping of Modern Knowledge (MIT, 2016).

As Tarbuck turns to the Account's literary and philosophical contexts, she demonstrates an impressive grasp of the high stakes of gendering Enlightenment through this document. If the Club was a search for an alternative environment that Enlightenment institutions could not provide,

was it necessarily a Habermasian alternative? Public sphere-private sphere discussions in the historiography seem to be challenged by a situation where ladies are found to have joined in the so-called public sphere, and treated the sphere, hitherto regarded as private, as a public one.

To unravel this gendered twist on our standard accounts of eighteenth-century sociability, Tarbuck makes an important intervention in the scholarship of women writers as well as of men. The Bluestockings, she notes, are often presented as the first female intellectual circle in Britain, but they were "by no means an organized sociability to the extent of the Fair Intellectual-Club."

Tarbuck does a masterful job situating the Account and her analysis in a previous work on women writers, sociability, and Scotland by Elizabeth Eger and Karen O'Brien. The Fair Intellectuals not only predate the efforts of Eger's Bluestockings but also anticipate the future: they deploy the term "intellectual," argues Tarbuck, in an almost "modern sense of the word." And they do that in Scotland, fulfilling, Tarbuck points out, O'Brien's call for more research to be done to show "the full extent to which those conversations [on the intellectual sociability of women] took place in a Scottish, as well as an English, accent." 
The "Foundations" section of the monograph shows why these claims matter by arguing that the Fair Intellectual Club "provides a platform for discussion on questions about the intellectual identity, and the responsibility that comes with it, of a learned person, in addition to his or her role as an active agent in the production of knowledge in the eighteenth century." Tarbuck outlines how they centered learning and knowledge as a means of "mutual improvement." And they did so, it turns out, in an "organized" and "methodical" way that may have inspired others. Tarbuck has uncovered a quite wonderful possible example:

In 1722, a spelling book for Scottish Ladies was published by James Robertson entitled The Ladies' Help to Spelling in Glasgow . . . that Charles Jones argued . . . was 'perhaps a response to the establishment in Edinburgh in 1720 of the all female Intellectual Club.'

If true, then the "improvement" these teenagers sought was even more "mutual" than they intended. This helps to explain why and how, as Tarbuck puts it, "members of the Club saw themselves as both active agents in the production and sharing of knowledge and as morally responsible for pursuing a life of the mind."

The section on "Leisure" that follows clarifies the particular shape that concept takes when we apply it to the situation of young women in early eighteenth-century Scotland. "It is especially worth noting," writes Tarbuck, "that the age of fifteen, which is the age at which the formal education of a young lady would cease, was chosen as the entrance age for the Fair Intellectual Club." Leisure, then, was the condition of possibility for what their society's institutions did not provide-and that these women chose to invent. Tarbuck notes that we don't know whether they had read the Proposal Mary Astell had published two decades earlier: a plan for a female academy. Whether they read it or not, they knew they were onto something new. In forming this Club, wrote Mrs. Speaker in the Account, "we are entering, as adventurous sailors into a new discovered land." That was a hard task, requiring them to navigate, as this study details, an "interplay between Reason and Religious belief." Derya Gürses Tarbuck deserves much credit for helping us to experience their journey. 
